\title{
PENGARUH BPJS KETENAGAKERJAAN DALAM MENINGKATKAN KESEJAHTERAAN TENAGA KERJA
}

\author{
Hafiz Sutrisno \\ Fakultas Hukum \\ Universitas Pahlawan Tuanku Tambusai \\ hafizsutrisno@yahoo.co.id
}

\begin{abstract}
Workers in Indonesia now really need a social security for themselves, because with the social security received by them makes them more focused in carrying out their duties to completion. The existence of social security provided will increase the welfare of the workforce itself and have a good impact on the survival of their families in the future if one day there is an accident of work from these workers when they carry out their duties the family can enjoy financial assistance from the government through social security. This study uses qualitative methods, namely research procedures that produce descriptive data in the form of written or spoken words from people or observable behavior. This method also comes from actions that are used as an understanding based on phenomena that occur in society, especially workers. In giving effect to the workers, BPJS Ketenagakerjaan has functions for workers, namely: Organizing work accident insurance programs, Organizing death insurance programs, Conducting old age insurance programs, Organizing pension insurance programs. The conclusion of this research is that there are still many companies that do not give rights to their workforce, that is, they do not take care of BJPS Ketenagakerjaan, which is a matter that must be obtained by each workforce. And the lack of awareness of the workforce about the benefits of BPJS Ketenagakerjaan for them in the event of a work accident.
\end{abstract}

Keywords: BPJS Ketenagakerjaan, Welfare, Employee

\begin{abstract}
ABSTRAK
Tenaga kerja di Indonesia saat ini sangat memerlukan adanya jaminan sosial bagi diri mereka, karena dengan adanya jaminan sosial yang diterima oleh mereka membuat mereka semakin fokus dalam melaksanakan tugasnya hingga selesai. Dengan adanya jaminan sosial yang diberikan akan menaikkan kesejahteraan dari tenaga kerja itu sendiri dan berdampak baik untuk kelangsungan hidup keluarga mereka nantinya jika suatu saat terjadi kecelakaan kerja dari tenaga kerja tersebut ketika mereka melaksanakan tugasnya keluarga bisa menikmati bantuan dana dari pemerintah melalui jaminan sosial tersebut. Penelitian ini menggunakan metode kualitatif, yaitu prosedur penelitian yang menghasilkan data deskriptif berupa kata-kata tertulis atau lisan dari orang-orang atau perilaku yang dapat diamati. Metode ini juga berasal dari tindakan yang dijadikan sebagai pemahaman berdasarkan fenomena yang terjadi pada masyarakat, khususnya para pekerja. Dalam memberikan pengaruh terhadap para tenaga kerja, BPJS Ketenagakerjaan memiliki fungsi bagi tenaga kerja, yaitu: Menyelenggarakan program jaminan kecelakaan kerja, Menyelenggarakan program jaminan kematian, Menyelenggarakan program jaminan hari tua, Menyelenggarakan program jaminan penisun. Kesimpulan pada penelitian ini masih banyaknya perusahaan yang tidak memberikan hak bagi tenaga kerjanyanya yaitu tidak menguruskan BJPS Ketenagakerjaan tenaga kerjanya yang notaben merupakan suatu hal yang wajib didapatkan oleh setiap tenaga kerja. Serta kurangnya kesadaran dari tenaga kerja tentang manfaat BPJS Ketenagakerjaan bagi mereka jika terjadi kecelakaan kerja.
\end{abstract}

Kata kunci: BPJS Ketenagakerjaan, Kesejahteraan, Tenaga Kerja 


\section{PENDAHULUAN}

Negara Indonesia merupakan negara yang sangat pesat pembangunannya. Pondasi pembangunan negara Indonesia pertama kali dicetus oleh mantan presiden ke-2 indonesia yaitu Bapak Soeharto, yang mana beliau didaulat sebagai Bapak Pembangunan Indonesia atas jasa beliau selama menjabat sebagai Presiden Republik Indonesia.

Dalam pembangunan di Indonesia tentunya ada peran masyarakat disini selain peran dari pemerintah, peran tersebut dalam bidang jasa (tenaga kerja). Tenaga kerja menurut Pasal 1 angka 2 UU No 13 tahun 2003 tentang ketenagakerjaan adalah setiap orang yang mampu melakukan pekerjaan guna menghasilkan barang dan/atau jasa untuk memenuhi kebutuhan sendiri maupun untuk masyarakat. Tenaga kerja sangat dibutuhkan dalam pembangunan di Indonesia dari setelah proklamasi kemerdekaan hingga saat ini.

Tenaga kerja di Indonesia merupakan tenaga kerja yang lumayan banyak jumlahnya. Dengan adanya tenaga kerja ini otomatis pemerintah tidak perlu pusing untuk memilih pekerja dalam suatu bidang, baik di bidang infrastruktur, kesehatan, hukum dan lain-lain di Indonesia sudah teresedia seluruhnya.

Tenaga kerja di Indonesia saat ini sangat memerlukan adanya jaminan sosial bagi diri mereka, karena dengan adanya jaminan sosial yang diterima oleh mereka membuat mereka semakin fokus dalam melaksanakan tugasnya hingga selesai. Dengan adanya jaminan sosial yang diberikan akan menaikkan kesejahteraan dari tenaga kerja itu sendiri dan berdampak baik untuk kelangsungan hidup keluarga mereka nantinya jika suatu saat terjadi kecelakaan kerja dari tenaga kerja tersebut ketika mereka melaksanakan tugasnya keluarga bisa menikmati bantuan dana dari pemerintah melalui jaminan sosial tersebut.
Dalam Undang-undang Dasar Negara Republik Indonesa Tahun 1945, dijelaskan mengenai jaminan sosial bagi tenaga kerja pada Pasal 28H ayat (3) UUD 1945 :"Setiap orang berhak atas jaminan sosial yang memungkinkan pengembangan dirinya secara utuh sebagai manusia yang bermartabat." Selain itu juga di jelaskan dalam Pasal 34 ayat (2) UUD 1945: "Negara mengembangkan sistem jaminan sosial bagi seluruh rakyat dan memberdayakan masyarakat yang lemah dan tidak mampu sesuai dengan martabat kemanusiaan."

Jaminan sosial bagi tenaga kerja sudah tertuang dalam aturan yang di buat oleh pemerintah. Pemerintah sangat mengapresiasi tenaga kerja yang ada di Indonesia dengan memberikan berupa jaminan sosial bagi mereka, yaitu dalam bentuk BPJS Ketenagakerjaan (Badan Penyelenggara Jaminan Sosial) Ketenagakerjaan. Yang mana BPJS Ketenagakerjaan ini didapat ketika mereka diterima menjadi pekerja (tenaga kerja) disuatu badan atau perusahaan serta lapangan kerja lainnya tanpa terkecuali.

BPJS Ketenagakerjaan sangat diwajibkan bagi tenaga kerja untuk memilikinya, jika masih ada tenaga kerja yang tidak memiliki BPJS Ketengakerjaan tersebut akan berdampak dikenakannya sanksi bagi perusahaan pemberi kerja tersebut akan dikenakan sanksi administratif, yaitu:

1. Sanksi Tertulis

2. Denda

3. Sanksi tidak akan mendapat pelayanan publik, meliputi perizinan usaha, mempekerjakan tenaga kerja asing, mengikuti tender suatu proyek dan Izin Mendirikan Bangunan (IMB).

Berbicara mengenai jaminan sosial bagi tenaga kerja, jaminan sosial terbagi kedalam beberapa jenis, yaitu:

a. Jaminan kesehatan

b. Jaminan kecelakaan kerja 
c. Jaminan hari tua

d. Jaminan pensiun

e. Jaminan kematian

Banyaknya jaminan sosial bagi tenaga kerja yang diberikan oleh pemerintah bukan menjadi jaminan bagi tenaga kerja bisa menikmatinya, karena masih banyaknya perusahaan yang nakal atau tidak mematuhi aturan yang dibuat pemerintah dengan alasan tidak mau merugi membayar iuran jaminan sosial tersebut. Akibatnya para tenaga kerja hanya pasrah menerima keadaan mereka tersebut dengan alasan jika mereka menuntut akan diberhentikan secara sepihak oleh perusahaan tersebut.

Bagi tenaga kerja, mereka sangat membutuhkan adanya jaminan sosial tersebut, jika hal tersebut diberikan bukan tanpa alasan para tenaga kerja tersebut tidak perlu lagi memikirkan kejadian yang diluar dugaan mereka, namanya saja bekerja tentu ada hal yang tidak diinginkan terjadi. Dalam hal bekerja sebagai pekerja pembangunan gedung tinggi misalnya, jaminan sosial ini sangat mereka perlukan, karena tidak tahu akan terjadi naas bagi mereka yang mengakibatkan kecelakaan kerja dan bisa membuat mereka cacat atau hal yang lebih buruk yaitu meninggal dunia. Perlunya jaminan sosial ini harus menjadi perhatian bagi pemerintah untuk memberikan teguran atau razia kepada perusahaan yang tidak mendaftarkan tenaga kerja mereka kedalam anggota jaminan sosial tersebut.

Banyaknya pekerja yang tidak memiliki jaminan sosial menjadi perhatian serius bagi pemerintah sebagai badan yang bertanggung jawab dalam menyelesaikan permasalahan ini. Hanya itu yang mereka harapkan, apalagi tenaga kerja tersebut bekerja diperusahaan swasta yang notabene jaminan dihari tua mereka tidak ada dan jika terjadi sesuatu hal yang tidak diinginkan dengan tidak memiliki BPJS Ketenagakerjaan membuat mereka pasrah dengan keadaan mereka. Apalagi kita tahu di Indonesia tidak ada yang gratis, semuanya mahal. Sebelum berobat tentunya kita akan mengurus administrasi, dari mana biaya yang akan kita keluarkan nantinya untuk kita berobat jika kita tidak memiliki BPJS Ketenegakerjaan tersebut.

Sejauh ini BPJS Ketenagakerjaan sangat membantu dan menjadi pelindung bagi para tenaga kerja yang mengalami kecelakaan kerja, Perlindungan tenaga kerja dimaksudkan untuk menjamin berlangsungnya sistem hubungan kerja secara harmonis tanpa disertai adanya tekanan dari pihak yang kuat terhadap pihak yang lemah. Dengan adanya perlindung dari BPJS Ketenagakerjaan tersebut mereka tidak perlu pusing lagi untuk memikirkan biaya pengobatan, karena semuanya sudah diurus oleh pemerintah dan perusahaan tempat mereka bekerja. Untuk itu sangat penting bagi tenaga kerja mendapatkan hak mereka dalam hal jaminan sosial ini.

Berdasarkan permasalahan diatas, penulis memberikan judul pada pembahasan ini dalam sebuah penelitian yaitu Pengaruh BPJS Ketenagakerjaan Dalam Meningkatkan Kesejahteraan Tenaga Kerja.

\section{METODE}

Penelitian ini menggunakan metode kualitatif, yaitu prosedur penelitian yang menghasilkan data deskriptif berupa katakata tertulis atau lisan dari orang-orang atau perilaku yang dapat diamati. Metode ini juga berasal dari tindakan yang dijadikan sebagai pemahaman berdasarkan fenomena yang terjadi pada masyarakat, khususnya para pekerja. Penelitian dilakukan pada bulan Februari - April 2019.

\section{HASIL}

$\begin{array}{ccc}\text { Sejarah } & \text { terbentuknya } & \text { BPJS } \\ \text { Ketenagakerjaan } & \text { yang } & \text { dahulu } \\ \text { bernama Jamsostek mengalami } & \text { proses }\end{array}$ yang panjang, dimulai dari UU No.33/1947 jo UU No.2/1951 tentang kecelakaan kerja, Peraturan Menteri Perburuhan (PMP) No.48/1952 jo PMP No.8/1956 tentang pengaturan bantuan untuk usaha penyelenggaraan kesehatan buruh, PMP 
No.15/1957 tentang pembentukan Yayasan Sosial Buruh, PMP No.5/1964 tentang pembentukan Yayasan Dana Jaminan Sosial (YDJS), diberlakukannya UU No.14/1969 tentang Pokok-pokok Tenaga Kerja. Secara kronologis proses lahirnya asuransi sosial tenaga kerja semakin transparan.

Setelah mengalami kemajuan dan perkembangan, baik menyangkut landasan hukum, bentuk perlindungan maupun cara penyelenggaraan, pada tahun 1977 diperoleh suatu tonggak sejarah penting dengan dikeluarkannya Peraturan Pemerintah (PP) No.33 tahun 1977 tentang pelaksanaan program asuransi sosial tenaga kerja (ASTEK), yang mewajibkan setiap pemberi kerja/pengusaha swasta dan BUMN untuk mengikuti program ASTEK. Terbit pula PP No.34/1977 tentang pembentukan wadah penyelenggara ASTEK yaitu Perum Astek.

Tonggak penting berikutnya adalah lahirnya UU No.3 tahun 1992 tentang Jaminan Sosial Tenaga Kerja (JAMSOSTEK). Dan melalui PP No.36/1995 ditetapkannya PT Jamsostek sebagai badan penyelenggara Jaminan Sosial Tenaga Kerja. Program Jamsostek memberikan

perlindungan dasar untuk memenuhi kebutuhan minimal bagi tenaga kerja dan keluarganya, dengan memberikan kepastian berlangsungnya arus penerimaan penghasilan keluarga sebagai pengganti sebagian atau seluruhnya penghasilan yang hilang, akibat risiko sosial.

Selanjutnya pada akhir tahun 2004, Pemerintah juga menerbitkan UU Nomor 40 Tahun 2004 tentang Sistem Jaminan Sosial Nasional. Undang-undang itu berhubungan dengan Amendemen UUD 1945 tentang perubahan pasal 34 ayat 2, yang kini berbunyi: "Negara mengembangkan sistem jaminan sosial bagi seluruh rakyat dan memberdayakan masyarakat yang lemah dan tidak mampu sesuai dengan martabat kemanusiaan". Manfaat perlindungan tersebut dapat memberikan rasa aman kepada pekerja sehingga dapat lebih berkonsentrasi dalam meningkatkan motivasi maupun produktivitas kerja.

Kiprah Perusahaan yang mengedepankan kepentingan dan hak normatif Tenaga Kerja di Indonesia terus berlanjut. Sampai saat ini, PT Jamsostek (Persero) memberikan perlindungan 4 (empat) program, yang mencakup Program Jaminan Kecelakaan Kerja (JKK), Jaminan Kematian (JKM), Jaminan Hari Tua (JHT) dan Jaminan Pensiun (JP) bagi seluruh tenaga kerja dan keluarganya.

Tahun 2011, ditetapkanlah UU No 24 Tahun 2011 tentang Badan Penyelenggara Jaminan Sosial. Sesuai dengan amanat undang-undang, tanggal 1 Januri 2014 PT Jamsostek akan berubah menjadi Badan Hukum Publik. PT Jamsostek tetap dipercaya untuk menyelenggarakan program jaminan sosial tenaga kerja, yang meliputi JKK, JKM, JHT dengan penambahan Jaminan Pensiun mulai 1 Juli 2015.

Pada tahun 2014 pemerintah menyelenggarakan program Jaminan Kesehatan Nasional (JKN) sebagai program jaminan sosial bagi masyarakat sesuai UU No. 24 Tahun 2011, Pemerintah mengganti nama Askes yang dikelola PT Askes Indonesia (Persero) menjadi BPJS Kesehatan dan mengubah Jamsostek yang dikelola PT Jamsostek (Persero) menjadi BPJS Ketenagakerjaan.

BPJS Ketenagakerjaan selaku jaminan sosial yang diberikan pemerintah kepada tenaga kerja memiliki manfaat antara lain, yaitu:

1. Mendapat Jaminan Kecelakaan.

Jika mengalami kecelakaan, karyawan akan mendapat jaminan kecelakaan berupa perawatan medis dari rumah sakit pemerintah. Perawatan ini meliputi biaya pemeriksaan, biaya penyembuhan dan lanjutan, serta biaya rawat inap kelas I.

Jaminan kecelakaan yang diberikan bukan untuk kejadian di tempat kerja saja, tetapi di seluruh tempat. Apabila 
terdapat biaya lain-lain selama proses pengantaran ke rumah sakit, peserta akan mendapat biaya penggantian uang berupa ongkos transportasi dan lain-lain.

2. Mendapat Santunan Kematian.

Jika kecelakaan yang terjadi menyebabkan karyawan kehilangan nyawa atau meninggal, BPJS ketenagakerjaan akan memberikan santunan kepada keluarga yang ditinggalkan. Jumlah santunan sebesar Rp 36 juta dan akan diberikan kepada ahli waris dari peserta BPJS ketenagakerjaan.

Apabila kecelakaan tersebut terjadi di tempat kerja, santunan yang diberikan sebesar 48 kali gaji terakhir peserta BPJS ketenagakerjaan. Apabila gaji per bulan sebesar Rp 8 juta maka pemerintah akan memberikan Rp 8 juta selama 48 kali kepada keluarga yang ditinggalkan.

3. Tabungan Untuk Hari Tua.

Iuran BPJS ketenagakerjaan yang dibayarkan setiap bulan dapat dialihkan menjadi tabungan hari tua bersamaan dengan hasil pengembangannya.

Menurut regulasi dan ketetapan BPJS, pengembangan yang diberikan tidak boleh lebih kecil daripada bunga deposito yang diberikan oleh bank. Dengan kata lain, hasil pengembangan BPJS ketenagakerjaan lebih tinggi daripada bunga bank.

Kini tabungan atau jaminan hari tua dapat dicairkan sebelum pensiun atau setelah 10 tahun bekerja. Namun, pencairan JHT hanya sebesar 10 persen saja dan sebesar 30 persen bagi karyawan yang masih aktif bekerja.

Bisa dicairkan 100 persen jika karyawan terkena PHK atau resign, sebelum atau sesudah bekerja lagi tapi belum terhitung mendapatkan fasilitas BPJS Ketenagakerjaan dari perusahaan yang baru.

4. Mendapat Uang Pensiunan.
Pemberian uang pensiun memang identik khusus untuk Pegawai Negeri Sipil (PNS). Tapi bagi karyawan swasta, fasilitas pensiun juga bisa diperoleh melalui BPJS Ketenagakerjaan. Besar uang pensiun yang diberikan tidak penuh atau tidak sama dengan besar gaji pokok per bulan.

Apabila peserta meninggal dunia, maka ahli waris berhak mendapatkan uang pensiun terusan selama 4 bulan berturut-turut sejak yang bersangkutan meninggal. Sedangkan untuk presiden, TNI dan Polri yang berjasa bagi negara, maka pensiun terusan bisa lebih dari 4 bulan.

\section{PEMBAHASAN}

Dalam memberikan pengaruh terhadap para tenaga kerja, BPJS Ketenagakerjaan memiliki fungsi bagi tenaga kerja, yaitu:

1. Menyelenggarakan program jaminan kecelakaan kerja.

2. Menyelenggarakan program jaminan kematian.

3. Menyelenggarakan program jaminan hari tua.

4. Menyelenggarakan program jaminan penisun.

Dalam menjalankan fungsi tersebut, BPJS Ketenagakerjaan memiliki tugas, antara lain:

1. Melakukan dan/atau menerima pendaftaran peserta.

2. menyelenggarakan Memungut dan mengumpulkan iuran dari peserta dan pemberi kerja.

3. Menerima bantuan iuran dari Pemerintah

4. Mengelola dana jaminan sosial untuk kepentingan peserta

5. Mengumpulkan dan mengelola data peserta program jaminan sosial.

6. Memberikan informasi mengenai penyelenggaraan program jaminan 
sosial kepada peserta dan masyarakat.

Program ini memberikan perlindungan yang bersifat mendasar bagi peserta jika mengalami risiko-risiko sosial ekonomi dengan pembiayaan yang terjangkau oleh pengusaha dan tenaga kerja. Risiko sosial ekonomi yang ditanggulangi oleh Program Jamsostek terbatas yaitu perlindungan pada:

1. Peristiwa kecelakaan

2. Sakit

3. Hamil

4. Bersalin

5. Cacat

6. Hari tua

7. Meninggal dunia

Adapun sanksi jika perusahaan selain penyelenggara negara tidak melaksanakan kewajiban mendaftarkan pekerjanya sebagai Peserta kepada BPJS adalah sanksi administratif. Sanksi administratif itu dapat berupa:

1. Teguran tertulis : dilakukan oleh BPJS.

2. Denda; dan/atau : dilakukan oleh BPJS.

3. Tidak mendapat pelayanan publik tertentu : dilakukan oleh Pemerintah atau pemerintah daerah atas permintaan BPJS.

Sanksi tidak mendapat pelayanan publik tertentu yang dikenai kepada Pemberi Kerja Selain Penyelenggara Negara meliputi:

1. Perizinan terkait usaha;

2. Izin yang diperlukan dalam mengikuti tender proyek;

3. Izin memperkerjakan tenaga kerja asing;

4. Izin perusahaan penyedia jasa pekerja/buruh; atau

5. Izin mendirikan bangunan (IMB).

BPJS Ketenagakerjaan sejatinya diperuntukkan untuk para pekerja, terkadang bukan hanya perusahaan yang tidak mau mengurus hal tersebut melainkan terkadang ada juga tenaga kerja yang tidak mengerti mengenai pentingnya BPJS
Ketenagakerjaan dan tidak mengurus pembuatan BPJS Ketenagakerjaan tersebut karena minimnya ilmu pengetahuan mengenai hal ini, sehingga banyaknya perusahaan yang nakal menipu tenaga kerja mereka. Banyaknya perusahaan yang tidak mengurus atau mendaftarkan tenaga kerjanya menjadi anggota BPJS Ketenagakerjaan dikarenakan kurangnya pengawasan dari pemerintah sehingga banyaknya perusahaan yang tidak mengindahkan peraturan yang dibuat oleh pemerintah tersebut dan pada akhirnya membuat tenaga kerja merugi karena hak mereka tidak mereka dapatkan.

\section{KESIMPULAN}

1. Masih banyaknya perusahaan yang tidak memberikan hak bagi tenaga kerjanyanya yaitu tidak menguruskan BJPS Ketenagakerjaan tenaga kerjanya yang notaben merupakan suatu hal yang wajib didapatkan oleh setiap tenaga kerja

2. Kurangnya kesadaran dari tenaga kerja tentang manfaat BPJS Ketenagakerjaan bagi mereka jika terjadi kecelakaan kerja.

\section{DAFTAR PUSTAKA}

Lexy J. moeleong, Metodologi Penelitian Kualitatif, Bandung: PT Remaja Rosdakarya

Yusuf Subkhi, Perlindungan Tenaga Kerja Alih Daya (Outsourcing) Perspektif Undang-Undang Nomor 13 Tahun 2003 Tentang Ketenagakerjaan, UIN Maliki Malang, Malang, 2012

Undang-undang Dasar Negara Republik Indonesia Tahun 1945

Undang-Undang Nomor 13 Tahun 2003 Tentang Ketenagakerjaan.

Undang-undang Nomor 40 Tahun 2004 tentang Sistem Jaminan Sosial Nasional. 
Undang-undang Nomor 24 tahun 2011 tentang Badan Penyelenggara Jaminan Sosial

Peraturan Pemerintah Republik Indonesia Tahun 2013 Tentang Tata Cara Pengenaan Sanksi Administratif Kepada Pemberi Kerja Selain Penyelenggara Negara Dan Setiap Orang, Selain Pemberi Kerja, Pekerja, Dan Penerima Bantuan Iuran Dalam Penyelenggaraan Jaminan Sosial.

Sejarah BPJS, https://id.wikipedia.org /wiki /BPJS_Ketenagakerjaan 